Paula Satizábal and Simon Batterbury. 2017. Fluid geographies: marine territorialisation and the scaling up of local aquatic epistemologies on the Pacific Coast of Colombia.

Transactions of the Institute of British Geographers http://dx.doi.org/10.1111/tran.12199

Accepted version, in press Aug 2017

Paula Satizábal, School of Geography, University of Melbourne ${ }^{1}$

Simon Batterbury, LEC, Lancaster University and School of Geography, University of

Melbourne

Key words: territory, geographies of the sea, marine protected areas, - conservation, Afrodescendants, Colombia

\begin{abstract}
The Pacific region of Colombia, like many sparsely populated places in developing countries, has been imagined as empty in social terms, and yet full in terms of natural resources and biodiversity. These imaginaries have enabled the creation of frontiers of land and sea control, where the state as well as private and illegal actors have historically dispossessed Afrodescendant and indigenous peoples. This paper contributes to the understanding of territorialisation in the oceans, where political and legal framings of the sea as an open-access public good have neglected the existence of marine social processes. It shows how Afrodescendant communities and non-state actors are required to use the language of resources, rather than socio-cultural attachment, to negotiate state marine territorialisation processes. Drawing on a case study on the Pacific coast of Colombia, we demonstrate that Afrodescendant communities hold local aquatic epistemologies, in which knowledge and the production of space are entangled in fluid and volumetric spatio-temporal dynamics. However, despite the social importance of aquatic environments, they were excluded from Afro-descendants' collective territorial rights in the 1990s. Driven by their local aquatic epistemologies, coastal communities are reclaiming authority over the seascape through the creation of a marine protected area.We argue that they have transformed relations of authority at sea to ensure local access and control, using state institutional instruments to subvert and challenge the legal framing of the sea as an open access public good. As such, this marine protected area represents a place of resistance that ironically subjects coastal communities to disciplinary technologies of conservation.
\end{abstract}

\title{
Introduction
}

During the opening ceremony of the second Colombian Protected Areas Congress 'Protected areas: territories for peace and life' held in Bogotá (2014), a Kogi indigenous leader from the Sierra Nevada de Santa Marta demanded that traditional authorities be recognised as central to the discussion of the use and management of ancestral territories located in the

\footnotetext{
${ }^{1}$ Acknowledgements. We acknowledge the support from communities in the Gulf of Tribugá and Los Riscales Community Council. We are indebted to the Gulf of Tribugá Environmental Ordinance Roundtable for facilitating this research. Funding was provided by the Francisco José de Caldas Scholarship from Colciencias and the University of Melbourne. We thank C. Jayasuriya for creating the maps. Special thanks to C. Vieira and C. Rincón from the MarViva Foundation, W. Dressler, J.C. Cárdenas, H. Rangan, J.E. Murillo, O. Saya, L.A. Perea, G. Ortiz, T. Toumbourou, L. Hanlon (Lever) and S. Duchêne for sharing their experiences, comments and insights. We acknowledge the Editor and three anonymous reviewers for their valuable comments and suggestions.
} 
Sierra Nevada National Natural Park. His message reflects a long history of conflicts between communities and protected areas in Colombia (Andrade 2009; Bocarejo and Ojeda 2016; De Pourcq et al. 2017; Ojeda 2012). He was followed by an Afro-descendant leader from the Gulf of Tribugá, who called for support for the declaration of a Marine Protected Area (MPA) to defend his collective territory from the destructive impacts of industrial fisheries (this MPA was established in late 2014). In his view, MPAs were allies in local territorial protection. Like him, several coastal peoples around the globe have supported or promoted the creation of marine conservation enclosures, relying on them as instruments to legitimise their local control and authority over the sea (see Benjaminsen and Bryceson 2012; Berlanga and Faust 2007; Nietschmann 1995; Rodríguez-Martínez 2008).

MPAs became globally enforced in the 1990s, when neoliberal approaches to environmental and fisheries governance centred on the creation of enclosures and property right regimes to control the access and use of marine resources (Mansfield, 2004a). ${ }^{2}$ Conversely, it has been shown that once an MPA has been established, coastal dwellers are very often marginalised, given their lack of power against government officials, conservation Non-Governmental Organisations (NGOs), and other key actors (Berlanga and Faust 2007; Chuenpagdee et al. 2013; Nietschmann 1995).

There is an extensive literature on land-based conservation territorialisation processes (Brad et al. 2015; Igoe and Brockington 2007; Peluso and Lund 2011). Corson (2011) and Roth (2008) argued territorialisation processes are produced by the active negotiation between the state and non-state actors over the access to and control over occupied landscapes. However, conservation enclosures often displace and dispossess marginal groups (Benjaminsen and Bryceson 2012; Bennett et al. 2015; Brondo and Bown 2011; West 2006). Territorialisation processes at sea are particularly complex because the oceans have been legally and politically framed as unoccupied and empty of social institutions, reducing them to open access spaces (Chmara-Huff 2014; Mansfield 2001; Mulrennan and Scott 2000; Russ and Zeller 2003; Steinberg 1999). The analysis of marine territorialisation processes has mainly focused on the role played by states, markets, conservation initiatives, and communities in controlling access and use of marine resources (Cardwell and Thornton 2015; Mansfield 2004a; St. Martin 2001). However, the extent to which marine territorialisation processes are also determined by socio-cultural dynamics that take place at the interface between land and sea remains unknown.

Geographers of the sea have pushed for a more critical engagement with oceans, moving beyond land/social and sea/resources binaries through the recognition of waterscapes as social spaces (Steinberg 2001; St. Martin 2005; Steinberg and Peters 2015). Our contribution is to show how particular coastal dwellers navigate the state institutional apparatus, informed by their 'local aquatic epistemologies' (LAEs), and drawing on territorialisation instruments to defend their coastal-marine territorial rights. We draw on LAEs, a term coined by Oslender (2016), that links the 'aquatic space', defined as the "assemblage of spatial relations that results from human entanglements with an aquatic environment” $(2016,47)$ to cultural and place-based ways of knowing. 'Local' not as a fix spatial entity that can be separated from a global scale, but as a relational scale that is co-constituted by dynamic, material, and symbolic settings where daily socio-natural interactions and relations are created, maintained,

\footnotetext{
${ }^{2}$ Neoliberalism not as a monolithic entity, but "a political economic approach that posits markets as the ultimate tool for achieving optimal use and allocation of scarce resources” (Mansfield 2004b, 565).
} 
and transformed (Brown and Purcell 2005; Oslender 2016, 34-35). We also draw on Elden's work on territory, which uses Foucault's theory of power to define territory as a political technology with a collection of techniques "for measuring land and controlling terrain" (2010, 799). Land, in this definition, is conceived as a scarce resource distributed and owned, while terrain is land that has political strategic relations of power important for the maintenance of order (Elden 2010). We bring these theories together to explore the interactions between LAEs and marine territorialisation processes. The engagement of Afrodescendant people in the creation of an MPA in the northern Pacific coast of Colombia results from the absence of legal institutions that would enable them to expand their territorial rights towards the sea. In doing this, we add to the broader theoretical debate on territory, showing that LAEs are informing the construction of terrain in the MPA.

To develop this argument, we demonstrate that Afro-descendant communities in the Gulf of Tribugá hold relational LAEs, where past and present knowledge results from individual and collective experiences entangled in marine and riverine spatio-temporal dynamics. Social and physical attachment to place has been sustained by memories of these experiences, which involves the emergence of shared symbolic meanings and a sense of place (Scannell and Gifford 2010). The state has rendered these local epistemologies invisible, instead imagining space as static, bounded, and 'empty-yet-full' - empty of people, or in some cases sparsely occupied, and yet full of resources and biodiversity (Bridge 2001). These static and bounded imaginaries have shaped the access and control of resource and wild frontiers, where traditional tenure arrangements are contested by modern enclosures linked to resource extraction and biodiversity conservation (Peluso and Lund 2011). Afro-descendant territorial rights were only granted in 1993, when the spatial logic of the state started disciplining local territorialities (Agnew and Oslender 2010). We show how coastal people, with the support of conservation NGOs, have been adopting state legal discourses and practices to reclaim the seascape as part of their territories. This process scaled up their LAEs to influence state territorialisation processes in a complex context of overlapping and contradictory jurisdictional arrangements, which involve state environmental and conservation authorities, as well as marine and terrestrial spatialities. Despite these efforts, the negotiation of the MPA remained centred on fishing resources and conservation of marine ecosystems, relegating socio-cultural dimensions to the background. This has led to the creation of spaces of resistance that subvert the legal framing of the ocean as a public space, yet subject local people to disciplinary conservation technologies and power asymmetries, which in this case are dominated by the capital accumulation interests of the fishing industry.

Our arguments are based on ethnographic and historical research carried out in Bogotá and nine coastal villages: Jurubirá, Tribugá, Nuquí, Panguí, Coquí, Joví, Termales, Partadó, and Arusí, in the Nuquí Municipality of Colombia from July 2014 to March 2015 (Figure 1). We consulted scientific papers, official documents, and NGO reports. We collected primary qualitative data from 94 semi-structured interviews with community leaders, NGO officials, academics, fisher people, and community members who participated in the declaration of the MPA, as well as government officials working in fisheries and environmental sectors at national, regional, and local levels. We included in the analysis information from participant observation, meetings, and informal conversations. The first author conducted interviews in Spanish and translated all quotes to English (see Supplementary Material for Spanish originals). We transcribed, coded, and analysed interviews and field notes according to emerging themes. This process was facilitated by the qualitative data analysis software NVivo (version 10.2.2). Participant identities are concealed. 


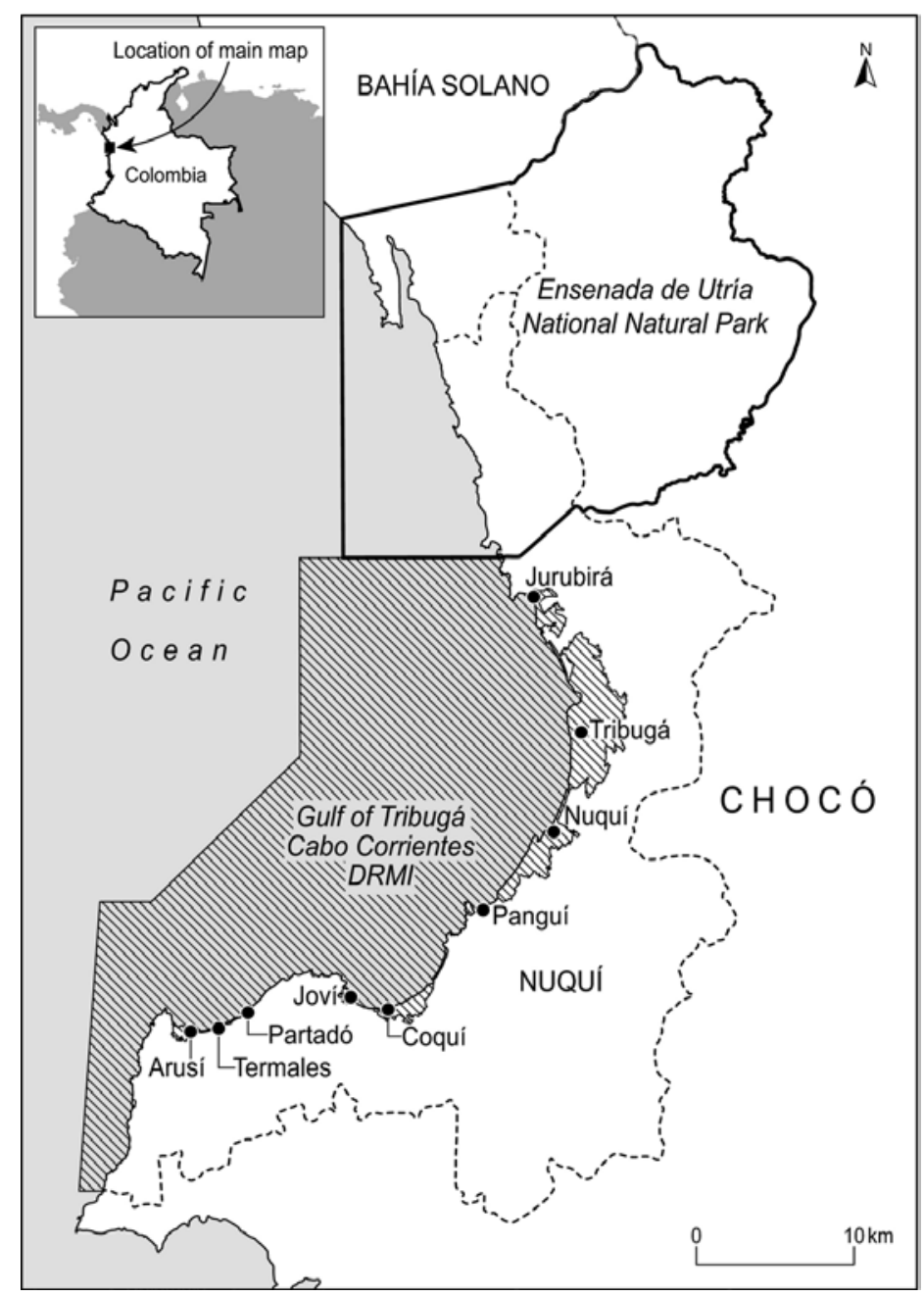

Figure 1. The Gulf of Tribugá and its nine coastal villages. At the North, the Ensenada de Utría, and at the South the Gulf of Tribugá - Cabo Corrientes Regional District of Integrated Management (Copyright Chandra Jayasuriya).

\section{Fluid geographies}

Many communities around the globe inhabit riverine and coastal areas, living in pulsing and dynamic waterspaces (Grundy-Warr et al 2015; Helmreich 2011; Steinberg 2013). Oslender has contributed to the understanding of these fluid geographies, drawing on ethnographic fieldwork in the Pacific lowlands of Colombia. His work has explored the way Afrodescendant subsistence activities and social relations have been spatialized along riverine basins, in what local people call 'the logic of the river' (2002, 94). Based on these complex dynamics, he developed the concept of aquatic space, where human and nonhuman elements create mutually constitutive relationships, entangling people in aquatic environments (2004, 2016). Past and present knowledge production and social relations in the aquatic space have constructed LAEs. Oslender argues that these localised knowledge systems have been the main 'site of contestation' of social movements along the Pacific coast, informing their local discourses and political practices (2016, 4). He draws on Lefebvre (1991), who divided social space into three interconnected moments: 'spatial practices', referring to everyday experiences and routines that shape peoples' perceptions and use of space; 'representational space', a lived space, linked to the construction of spatial imaginaries and symbols; and 'representations of space', the conceptualisation of space into abstract space (Oslender 2012). As noted by Lefebvre, the abstraction of space within modern capitalism embodies historical 
contradictions from conflicting social and political interests, that have subjected waterscapes and landscapes to constant spatial configuration and reconfiguration processes $(1991 ; 365)$. Oslender uses this spatial triad as an analytical tool to explore the 'differential space' that emerges in opposition to the homogenising forces of state abstract capitalist spaces (Lefebvre 1991, 52; Oslender 2012). However, he departs from Lefebvre in arguing that differential space arises not only as a process that opposes state abstract space, but in fact, have existed through time, becoming immortalised in the Pacific LAEs (Oslender 2016, 32). In this section, we explore the fluid geographies of Afro-descendant in the Pacific, to demonstrate that LAEs exist in the Gulf of Tribugá.

\section{From the rivers to the sea}

African slaves were forcedly brought from West and Central Africa to Colombia by the Spanish colony since the first decade of the $16^{\text {th }}$ century. They provided labour for colonial gold mining, agriculture, herding, boat construction, and domestic work (Friedemann 1993). Colonial alluvial gold mining reached the Pacific lowlands in the $16^{\text {th }}$ century and was complemented by subsistence fishing, hunting, and farming, in which the spatial and temporal fluidities of river basins became the centre of social interactions (Offen 2003; Oslender 2004). Slavery was abolished in 1851, after the declaration of independence from Spain in 1810. Freed Afro-descendant migrated along the rivers, mining independently (Oslender 2002). They interacted with indigenous peoples, in many cases establishing compadrazgo (godparenthood) relations that facilitated their survival in new environments (Wade 1995). Peoples' identities and epistemologies became shaped by the socio-ecological interactions along the riverine systems in which they resided.

At the end of the $19^{\text {th }}$ and during the $20^{\text {th }}$ century, clashes between the Liberal and Conservative parties exploded in two conflicts; the Thousand Days' War (1899-1902) and the Violencia civil war (1946-1966). During these periods, the territorial rights of Afrodescendant people remained unrecognised by the state. Many communities living along the northern Pacific river basins were displaced and dispossessed. They migrated towards the coast, including the Gulf of Tribugá, and settled around river deltas to trade and participate in boom-bust cycles of extractive economies (Offen 2003). This process involved readjusting to new environments, where the dynamics of the sea, river, moon, and forest shape space and time (García et al. 2014). However, the social memory of their riverine settlements and new experiences at sea continued to shape local identities and remained alive through storytelling, poetry, and songs (Oslender 2016, 90-91). In one interview, a woman from the Alto Baudó, explained how she belonged to the river. She recalled how her grandmother took her $a$ canalete (paddling a wooden canoe) to Nuquí more than 50 years ago, initially to crop rice, where she eventually learned how to live with the sea. At present, she is a piangüera; she follows the tides to harvest piangüa (Andara tuberculosa) and other shellfish. Her story reflects the history of those Afro-descendant that transitioned from the rivers to the sea, forging new social and cultural relations with marine spatio-temporal dynamics that we now explore.

\section{Local aquatic epistemologies}


The Gulf of Tribugá is located in the Nuquí Municipality, Chocó Department (Figure 1). ${ }^{3}$ There are nine coastal villages located along river mouths and streams, which are connected to a complex riverine system that drains from the Western Andean and Baudó ranges, passing through the tropical rainforest towards the Pacific Ocean. These villages are primarily inhabited by Afro-Descendant people as part of Los Riscales Collective Territory, formally titled in 2002. The inland part is divided into three Emberá indigenous resguardos (indigenous reserves), and the northern section is covered by the Ensenada de Utría National Natural Park (from here on referred as Ensenada de Utría). The coast has cliffs bordering coastal ranges, pocket beaches, and scattered mangrove swamps near Jurubirá, Tribugá, Nuquí, Panguí, and Coquí. Coastal and fluvial dynamics are influenced by high semi-diurnal tides and two main seasons; a dry summer takes places between December and April and a rainy winter from August to November. The fluid and mobile dynamics of tides and rain along the Gulf of Tribugá have shaped the lives of human and nonhuman inhabitants, not only as the background of spatial practices, but anchoring them material and symbolic socionatural worlds (Escobar 2008, 42-43).

In the Gulf, as in other places along the Pacific, the sea plays such an important role that for many daily activities are scheduled looking at the sea rather than the clock (Oslender 2016, 9; Vargas Sarmiento and Ferro Medina 1999,19). Respondents often suggested meeting when the tide was up or down, rather than any specific hour of the day. Tides have daily and monthly fluctuations that shape navigation patterns, social interactions, and subsistence practices. Semidiurnal tides move from low to high tides two times every lunar day. Wooden canoes are pushed by the flow upstream during high tides, and downstream during low tides. Tidal dynamics also respond to the cycle of the moon, transitioning every major lunar phase from high to low tidal ranges, traditionally known as puja and quiebra, each occurring two times per month. Puja takes place during the full and new moon, when strong currents and high tides flood beaches, river deltas, mangrove swamps, and coastal areas, transforming coastal villages into islands. Many coastal dwellers live in stilt houses, elevated by wooden structures locally known as palafitos. These houses are located along areas that can potentially get flooded during high puja tides. On the contrary, low tides uncover wide coastal flats, enabling people to walk from one village to the other and piangüeras to collect shellfish in mangrove swamps and intertidal muddy bottoms. Fishing becomes extremely difficult during the strong puja currents; most fishers shift to farming and even tourism, only venturing at sea for the pancoger (subsistence catches), or the pleasure of fishing.

Successively, tidal ranges and currents are reduced during the first quarter and last quarter moon phases, known as quiebra. Spatio-temporal dynamics are also shaped by rainfall seasonality and changes in the wind and sea surface temperature. For example, during high rainfall riverine discharges surge along the coast, increasing water currents and turbidity, flooding some portions of the landscape. As argued by local respondents, people avoid navigating upstream and fishing around river mouths. On dry and sunny days, riverine salinity increases and coastal water temperature decreases, enabling fishers to capture big pelagic fish species in shallow coastal waters.

Coastal communities have developed an 'amphibian culture', where practices, behaviours, and beliefs follow these marine rhythms, and they express a versatility in transitioning between aquatic and terrestrial livelihood strategies (Fals Borda 2002). Traditions, rituals,

\footnotetext{
${ }^{3}$ According the National Administrative Department of Statistics in 2005 Nuquí had a total population of 6,295 (8,668 projected for 2016), from which $77.5 \%$ were Afro-descendant, and 21.5\% were indigenous peoples.
} 
and ceremonies are rooted in this amphibian culture. One morning as we joined a group of people that were collecting shellfish during a low puja tide, a fisher from Tribugá told us he was destined to fish. He claimed that his mother had scraped the beak of a heron, and placed it over his navel during his birth in the ombligada ritual, passing onto him the heron's ability to find plenty of fish. She also used the umbilical cord and placenta to plant a tree, tying him to the land. Past and present knowledge production has created relational and fluid representational spaces, where humans and nature are interdependent (Escobar 2015). In his words:

"Here in the Gulf is the story of who we are. We are everything you see, we are sea, rain, and forest” (Supplementary Text S1).

Most fishers use wooden canoes hand-carved in the forest during the waning moon by Afrodescendant and Emberá indigenous canoe builders. Children learn to fish in the rivers, mangroves, and estuaries, which is also where women and older residents fish. For one fisher in Nuquí, only those fishing offshore (pescar afuera) are socially recognised as 'fishers', having access to social interactions and networks that only take place at sea. Small-scale fisheries are spatial and temporally heterogeneous. Fishers target multiple species, relying on diverse fishing gear. Fish catches are mostly for local subsistence, which provide essential protein in the local diet. However, local middlemen also trade fish from Jurubirá, Nuquí, Panguí, and Arusí in national markets. Regardless of these commercial relations, local respondents saw the sea as much more than a container for resources. In the words of a fisher from Tribugá:

"It is from there, from my childhood that my love for fishing arises. Because fishing for us means and symbolises happiness, harmony. Fishing is about luck and life experiences [...]. When you are in the open sea you are connected to nature, thought, body and soul are synchronised with the movement of the sea" (Supplementary Text S2).

For these people the sea is a lived space, where place is socially constructed by memories, emotions, and experiences. Fishers use terrestrial landmarks to locate traditional fishing grounds, known as riscales (marine basaltic rocks). They learn to read the coast, in order to find their way at sea. Each fishing ground has been produced by human and nonhuman interactions that are immortalised through storytelling practices that give meaning to place. Two fishers from Arusí explained that new riscales are found by those who explore or get lost, usually named by, or after, their discoverers, anchoring people to places in the sea. On this basis, fishing involves socio-cultural processes that keep alive ancestral memories. Moreover, community members in Nuquí, Panguí, Coquí, and Termales have transformed marine areas collectively, using mangrove timber to create artificial riscales locally known as payaos, to attract fish near the coast. The social and symbolic relations experienced in each village have created a sense of place that alters across space and over time. Importantly, these LAEs have been produced, maintained, and transformed through the active interactions between place-based, indigenous, and expert knowledges, that act as disciplinary forces that shape and control peoples' conducts (Foucault 1995, 27-28; Oslender 2012). We now draw on the concept of territory, exploring the abstract representations of space at play in the Pacific region and the territorial struggles of these coastal communities.

\section{The production of territory}


The concept of territory has been part of the discussion of Afro-descendant territorial rights since the late 1980s (Escobar 2008, 52-53). 'Territory’ emanates from Western European political thought, from the $17^{\text {th }}$ century onwards, encompassing a wide variety of meanings and theoretical debates (e.g. Agnew 1994; Cox 1991; Elden 2013a; Moore 2015). It is important to note that modern Eurocentric epistemology presumes the existence of an objective 'universal truth' and constructs reality through the structure of binary oppositions (e.g. marine/terrestrial, nature/culture, modern/traditional) (Quijano 2000). Within this dualistic way of thinking, space is bounded, homogeneous, and separated from place and time (Agnew 2011). Territory has primarily been defined in terms of property, as a delimited space controlled by the state or other powerful actors, where power is exercised uniformly across fixed geographic boundaries; terrestrial, static, and ahistorical (Elden 2010; Steinberg and Peters 2015). One example is the delimitation of marine territories by the 1982 United Nations Convention on the Law of the Sea (UNCLOS), when territorial waters were fixed from the coastal baseline up to $12 \mathrm{~nm}$ for most coastal states. This arbitrary definition overlooks the relationship between territory, state, and people (Moore 2015). Territory has also been defined in terms of jurisdiction, with the modern state as the arbiter of justice. Administrative units are controlled by a jurisdictional authority through morally binding rules that enclose land and people, failing to account for peoples' attachment to place (Moore 2014).

Stuart Elden has challenged the perception of territory as a flat space, analysing territorial struggles occurring beyond the surface, including airspace and the subsoil. He has argued that territorial struggles also occur over the control of volumes, vertically and volumetrically (Elden 2013b). Adding volumetric considerations is important, but it still emerges from a terrestrial notion of territory that neglects the fluidity of matter and humans, particularly in aquatic spaces, where dynamic forces produce movements that cannot be contained or defined solely by volume (Grundy-Warr et al. 2015; Steinberg and Peters 2015). The landwater binary has been enforced by the modern state, in which solid land is a social space, while the liquid sea is a place to compete for resources and territorial sovereignty, disregarding marine social processes (Steinberg 2013, 2001; Steinberg and Peters 2015). Elden draws on Foucault's technologies of power, to define territory as a political technology, where legal systems, statistics, myths, wars, and other tools of power create abstract and hegemonic spatial representations (Elden 2013a, 10-17, 2010). These representations collide with LAEs, where territory acquires meaning through varying everyday practices blurring the water/land divide (Brenner and Elden 2009). To conceptually link LAEs with the state's production of territory, we review the production of territory on the Pacific coast.

\section{Resource and wild frontiers}

The Colombian state has historically reproduced modern representations of territory throughout its history, excluding aquatic environments from peoples' territorial rights. In colonial times (1550-1810), the Spanish Crown controlled key trade and productive areas, but had limited territorial control in remote Pacific localities. These areas became a resource frontier, classified as baldíos (unused lands), owned by the Crown (Serje 2006). The baldíos became a powerful political technology, rendering Afro-descendant and indigenous traditional landownership regimes invisible in order to legitimise capital accumulation (Mollett 2015). Territory was produced in terms of property, passed to companies and individuals through concessions, licenses, and private titles, dispossessing local peoples' rights (Oslender 2016, 64; Serje 2006). The Political Constitution of 1886 replaced the 
federal state with a unitary one, and divided the national territory into jurisdictional administrative units (i.e. departments, which are further divided into municipalities) (Offen 2003). It stated that baldíos and all their public goods including rivers, sea, beaches, and mangrove swamps belonged to the state, becoming inalienable and imprescriptible, which means their property rights cannot be taken away from the state, and remain in force even when not exercised (Article 4). This persisted in the Political Constitution of 1991 (Article 102), and created a false imaginary of the Pacific region as static, flat, and bounded.

Frontier economies increased land disputes between local communities and the state, and between national elites represented by Liberal and Conservative parties. There were conflicts between political parties that led to the Thousand Days' War and the Violencia civil war, producing new waves of displacement and territorial struggles (Serje 2006). Capital accumulation processes extended along the Pacific region, including industrial fishing, logging, mangrove bark and timber extraction, petroleum exploration, mining, and cultivation of banana, cacao, rice, sugar cane, and African palm (Escobar 2008, 75; Restrepo 2013). These activities were intensified by the development plans of the National Planning Department since the 1970s, and the adoption of a neoliberal economic model during the late 1980s. Local resistance was confronted with new waves of violence (Escobar 2003; Restrepo 2013).

In the late $20^{\text {th }}$ century, resource frontier regions started to be perceived as wild frontiers that needed protection from human interventions. The Institute of Renewable Natural Resources and Environment, which was the national environmental authority from 1968 to 1993, started declaring national parks. The tropical ecosystems along the Pacific became framed as 'untouched', imagined as a 'natural museum' (Restrepo 2013). Colombia approved the 1992 International Convention on Biological Diversity (CBD) in 1994. Biodiversity became one of the region's most valuable economic assets, escalating processes of conservation by dispossession (Asher and Ojeda 2009). Friction between environmental agendas and extractive industries soon emerged, although from a local perspective national parks had been created without local consultation, leading to resistance and conflicts (Andrade 2009). For example, one fisher in Jurubirá, located south from the Ensenada de Utría, claimed that when the park was created in 1987, Afro-descendants living within its boundaries were evicted. Some families migrated northward to El Valle, or to Jurubirá, but others refused to leave and became 'illegal occupiers'. There have been prolonged conflicts between fishers and park officials over access to traditional fishing grounds lying just offshore.

The Political Constitution of Colombia acknowledged the rights of indigenous and Afrodescendant communities in 1991, defining the country as multicultural and pluri-ethnic. The constitution stated that Afro-descendant territories needed further protection (Transitory Article AT-55). Consequently, a social movement, the Process of Black Communities, was formed by more than 120 organisations, local leaders, and activists to push for Afrodescendant territorial rights (Grueso et al. 2003). The movement joined the biodiversity conservation networks involved in the Proyecto Biopacífico (Biopacific Project), from 19921998, under the state's sustainable development agenda (Restrepo 2013). Their participation enabled the inclusion of culture as part of biodiversity (Escobar 2001). The network advocated for territorial rights using a past-present-future perspective that accounted for local identities, traditions, and history of resistance, envisioning territory as a space for being (espacio para ser) (PCN 2008). They were very strategic - by attaching territory to the survival of culture, territorial claims were linked to the protection of cultural diversity, 
endorsed by Article 8 of the Constitution. Additionally, by ascribing culture as a component of biodiversity conservation, territorial claims were safeguarded by the CBD. Finally, Law 70 granted collective territorial rights to Afro-descendant communities in 1993.

Communities were forced to organise into community councils. Afro-descendant territorial claims were turned into terrestrial, bounded, and static collective property regimes, known as collective territories. One local leader recalled the afternoon an Afro-descendant man came to Tribugá and told them about Law 70. The man explained they needed to form a community council for their territorial rights to be recognised by the state. Unlike indigenous resguardos, Afro-descendant collective territories were not recognised as territorial entities, which means they cannot collect taxes or administer natural resources, and are not directly funded by the national budget (Ng'weno 2000, 33-34). The absence of administrative independence was considered by local leaders in the Gulf of Tribugá to be a threat to local autonomy. They claimed that local processes are dependent on financial aid from the municipality and other external sources. Moreover, national parks and public goods including mangrove swamps, river basins, or coastal seas were excluded from the titling process, leaving their territories incomplete. In the words of a local leader in Nuquí:

"It seems like people in the government were thinking, those blacks we will never let them get strengthened, they will never have autonomy" (Supplementary Text S3)

Unlike the terrestrial configurations of collective territories, the Los Riscales community council defined territory in their 2007 Ethno-Development Plan as:

"A place where culture is created and strengthened, where ancestral practices are maintained, mediated and constructed by a cosmovision that gives meanings and sense to space” (2007: 119, translated from Spanish, Supplementary Text S4).

Their definition overcomes land-water binaries and boundaries, by focusing on culture, practices, and the production of meaning. However, the state has neglected these local constructions, leading to struggles over authority along the Pacific waterscapes, as one government official puts it:

"Many argue that they [Afro-descendants] have a bearing on the marine territory, and that Law 70, which favours Afro-descendent communities, says they have authority over their territory. But, other laws of the country say that the marine territory belongs to the state. End of story” (Supplementary Text S5).

Communities claimed that the exclusion of mangrove swamps violates their constitutional right to ethnic and cultural diversity (Ng'weno 2000; Offen 2003). After multiple negotiations, some communities gained special concessionary status over mangrove swamps, while other (including those in the Gulf of Tribugá) successfully incorporated mangrove areas within their collective territories (García et al. 2014; Oslender 2012). Even if the collective territories have contributed to the recognition of local territorial rights, this has been partial, also acting as an imposed political technology.

Territorialisation processes in the Pacific have also been shaped by the arrival of armed conflicts between military forces and leftist guerrillas since the 1990s. This involved the 
incursions of Revolutionary Armed Forces of Colombia (FARC) and National Liberation Army (ELN). However, during the middle of the decade, paramilitary groups and criminal gangs also expanded along the region. Drug trafficking and extractive economies have thrived, in many cases interrupting and impeding the titling process, and exposing communities in remote areas to violence, massacres, forced recruitment, corruption, and displacement (Escobar 2003). The Gulf of Tribugá has been dramatically affected, particularly in Tribugá, where several armed incursions and forced displacements have occurred due to the ELN and paramilitary groups, the latest in 2014. During one interview, an academic linked this violence to the economic interests behind the construction and control over two still-unbuilt infrastructure projects; the Animas-Nuquí road, proposed by the state in 1959 to connect the northern Pacific coast to the national highway system, and a multipurpose port, which has been discussed by development agencies since 1989. Furthermore, illegal small-scale and large-scale gold mining has intensified in Chocó since the gold price increased in the 2000s (Tubb 2015, see Supplementary Text S6). At least 46\% of the alluvial gold exploitation occurs within Afro-descendants' collective territories in Chocó (UNODC and MINJUSTICIA 2016, 11). Some extraction is embedded in a very complex criminal web, linked to arms and drug trafficking, as well as money laundering. This has bankrolled and intensified an unconventional warfare, transforming local economies, and triggering major socio-environmental upheavals (Tubb 2015). We did not find evidence of illegal mining occurring along the coast of the Gulf of Tribugá, but local leaders claimed it takes place inland. Due to the interconnected and fluid spatio-temporal dynamics of waterscapes along the northern Pacific, the environmental impacts of illegal mining pose a major threat to riverine and coastal communities. The protection of Afro-descendant territorial rights in the post-conflict political scenario will be crucial since a peace agreement between the state and the FARC was signed the $24^{\text {th }}$ of November (2016), and mining and other armed groups may expand along the Chocó. Wild and resource frontiers have been central for the production of territory in the Pacific, historically dispossessing local communities from their lands and rights over aquatic environments through violent interventions. But, where is the sea in this history of disputed territorialisation?

\section{Territorial struggles at sea}

The state's production of marine territory replicates terrestrial imaginaries, where space has been perceived as empty-yet-full, flat, static, and bounded, valued for capital accumulation, national sovereignty, transportation services, and biodiversity conservation. Afrodescendants' traditions, fishing practices, social interactions, and collective memories at sea are still rendered invisible by the state. Marine industrial fisheries have targeted tuna, small pelagic fish, deep-water shrimp, shallow-water shrimp, and demersal fish. They operate large boats with specialised fishing gear fishing along the coast, relying on four major ports: Bahía Solano, Buenaventura, Guapí, and Tumaco (Figure 2) (Wielgus et al. 2010). Fisheries have been dramatically affected by overfishing, extreme El Niño Southern Oscillation phases, high fuel prices, habitat destruction and demand reduction, leading to the collapse of the shallowwater shrimp fishery during the 1980s and the carduma (Cetengraulis mysticetus) fishery in 2013 (Díaz-Ochoa and Quiñones 2008; Zapata et al. 2013). 


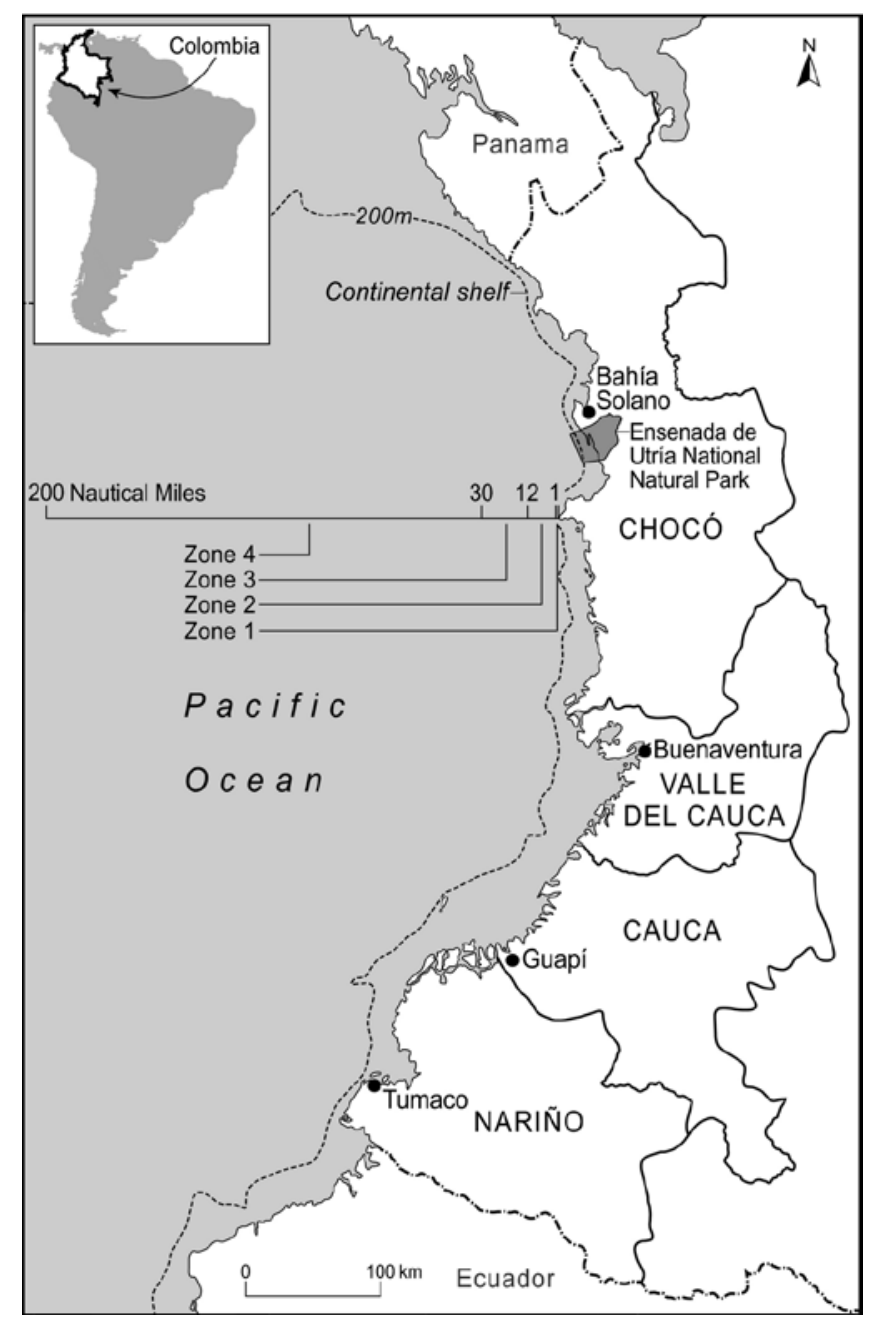

Figure 2. Map of the Pacific coast of Colombia showing: coastal departments, main marine ports, and $200 \mathrm{~m}$ isobath. One coastal point illustrates the extent of the four major fisheries exploitation zones (Copyright Chandra Jayasuriya).

Industrial and small-scale fisheries are still controlled by an outdated national fisheries policy, created before Afro-descendant and indigenous peoples' rights were recognised by the 1991 Political Constitution (General Fisheries Statute, Law 13 of 1990). Small-scale fishers have had limited articulation with external markets, which has historically excluded their LAEs and traditional fisheries governance systems from national and regional fisheries governance decision-making arenas (Saavedra-Díaz et al. 2015). Instead, fisheries governance relies mostly on top-down control mechanisms (e.g. annual fishing licenses, total allowable catch quotas and seasonal fishing bans). The institutional instability caused by six administrative changes to the 'fisheries authority" ${ }^{4}$ since the 1990 s, and the internal armed conflict have limited the implementation of control mechanisms (Saavedra-Díaz et al. 2015; Wielgus et al. 2010). The sea has also been a site of contestation between the state and illegal groups over the control of marine trafficking networks and corridors. All this has disrupted

\footnotetext{
${ }^{4}$ The fisheries authorities: Institute of Renewable Natural Resources and Environment (1968-1993); National Institute for Fisheries and Aquaculture (1990-2003); Colombian Institute for Rural Development (INCODER), (2003-2007); Colombian Agricultural Institute (2008-2009); INCODER (2009-2011); and National Authority for Aquaculture and Fisheries (2012-Present).
} 
the long-term assessment of fish stocks and marine ecosystems, as well as undermining the importance of small-scale fisheries for coastal food security.

From the 1990s, conflicts between coastal communities in the northern Pacific and the tuna and deep-water shrimp fisheries escalated. The tuna industry primarily targets Skipjack tuna (Katsuwonus pelamis) and yellowfin tuna (Thunnus albacares), using purse seines and long lines, with helicopters, echo sounders, and radar support (Melo Saldarriaga et al. 2011). Importantly, small-scale fishers also capture tuna using hand and long lines. Communities in Juradó and Bahía Solano accused this industry of threatening coastal food security due to overfishing and excessive bycatch (see next section). Moreover, the deep-water shrimp industry, which mostly captures coliflor shrimp (Solenocera agassizii) and pink shrimp (Farfantepenaeus brevirostris), uses double-bottom trawlers that operate on fishing grounds at $70 \mathrm{~m}$ of depth or more (Rodríguez et al. 2012). The industry also maximises profits by marketing bycatch and mid-water trawling catches of pelagic fish. Shrimp vessels are privately owned and are operated by about six crew members, most of which are Afrodescendants from Buenaventura (see Supplementary Table S1). According to a respondent during an informal conversation in Nuquí, several crew members have been treated at the local health post for undernourishment and other health issues associated with poor working conditions. Fishers in the nine coastal villages of the Gulf of Tribugá accused shrimp vessels of dragging away their long-lines and encroaching on local riscales. In the words of a fisher from Jurubirá:

"The industry is not respecting our places, our fishing grounds. Last year, two vessels were trawling here and dragged away our long-lines. We filed a complaint, but realised the owners of those vessels were people connected with the government, that is why they [fisheries authorities] didn't pay attention to us” (Supplementary Text S7).

Fishers along the Gulf blamed the industry for the reduction of fish stocks resulting from the impacts of high bycatch, noise pollution, seabed trawling. They referred to their territorial rights, questioning why the fisheries authority is granting fishing licences without local consultation. As recalled by a fisher in Arusí:

"Oh that is quite a fight! The boats [industrial] tell you that the sea has no owner, that the sea belongs to everyone, that the sea is not private, that they paid their taxes in Bogotá where they were given licenses and permits. But, we have a regulation [Law 70] that was given to us by the state to defend our territories. For whites, blacks, and indigenous to defend our territories. If they gave this to us, why are they coming from Valle [del Cauca] to destroy Chocó?” (Supplementary Text S8).

Local respondents and conservation NGO officials argued that the industry only uses the Gulf to fish without any return to local economies. A respondent in Panguí said:

"We don't benefit from anything, they [the industry] take out the production to their companies and greatly affect local fishers” (Supplementary Text S9).

In this context, in 2004 the fisheries authority divided the marine territory into four fishing zones (Figure 2). Zone 1 (shoreline to $1 \mathrm{~nm}$ ), exclusive to small-scale fisheries; Zone 2 (1-12 $\mathrm{nm}$ ), for shallow and deep-water shrimp, demersal species, and small/medium pelagic 
fishing; Zone 3 (12-30 nm), for deep-water shrimp, demersal species, and small/medium pelagic fisheries; and Zone 4 (30-200 nm), for oceanic and medium pelagic fisheries. The establishment of these zones reflected the UNCLOS marine territorial delimitation - it was arbitrary, non-consultative, and disregarded local and spatial heterogeneity (Saavedra-Díaz et al. 2015). Community leaders in the Gulf of Tribugá argued that local people with knowledge of small-scale fisheries were excluded, and that $1 \mathrm{~nm}$ is not enough to protect their fishing grounds from industrial fisheries. An academic claimed that the fisheries authority only consulted fishing industry representatives:

"Here to give artisanal fisheries space, they [the fisheries authority] consult the industry. To me this is evidence of the disequilibrium and strong influence of the industrial sector in the design of policies. We could even question what the government calls 'industrial sector participation', as an obstacle to the independence of the government decision-making” (Supplementary Text S10).

Importantly, the closest fisheries authority office is approximately two hours away by boat in Bahía Solano, which limits control and surveillance. As stated by a fisher in Nuquí:

"In January [2015], I was at the Playa Olímpica and a shrimp vessel was trawling less than a mile from the coast. I called the Navy lieutenant and he said 'I am looking out for the public order with respect to the issue of drug-trafficking' [...]. People can only sit and mourn, seeing how these vessels destroy our sea" (Supplementary Text S11).

The lack of involvement and participation of coastal Afro-descendant communities in the production of these marine territories means the sea is treated formally as a resource frontier. These zones act as a political technology that imposes boundaries defined by the fisheries authority, dispossessing communities from the fluidities of their marine social space. Several fishers interviewed around the Gulf of Tribugá claimed that the reduction of fish yields occasionally forces them to navigate further offshore. In general, the fisheries authority has overseen the dispossession of local small-scale fisheries, affecting local food security, environmental health, and cultural heritage. In doing this, extra-local capital accumulation processes have been prioritised and sustained (Sneddon 2007). This process has privileged the participation of industrial fisheries in governance decisions and has suppressed LAEs along the coast. Conflicts with the industry are not simply driven by the physical appropriation of resources, but by efforts to defend the sea as a social and cultural space.

\section{Marine wild frontiers}

Small-scale artisanal fishers in Juradó and Bahía Solano (Figure 3), have demanded a ban on industrial tuna and deep-water shrimp fishing since the 1990s. This is when the sea started to be a site of contestation between wild and resource frontiers. It was in 1992, when the CBD called for the identification of priority marine conservation areas, that this became a dominant objective in government policy (Wood et al. 2008). Importantly, in 2004 state nations that had ratified the CBD committed to the protection of at least $10 \%$ of national coastal and marine areas by 2012 (deferred until 2020 by the Aichi Target 11). In Colombia, the Institute of Marine and Coastal Research (INVEMAR) has identified priority conservation areas. MPAs are now declared by three state agencies: the fisheries authority 
(Exclusive Artisanal Fishing Zones and Special Fishing Management Zones - Law 13, 1990), the National Natural Parks System, and regional environmental authorities known as Autonomous Regional Corporations. The latter were granted marine jurisdiction within 12 $\mathrm{nm}$ from the coast (Law 1450) in 2011, to assist in the creation of MPAs.

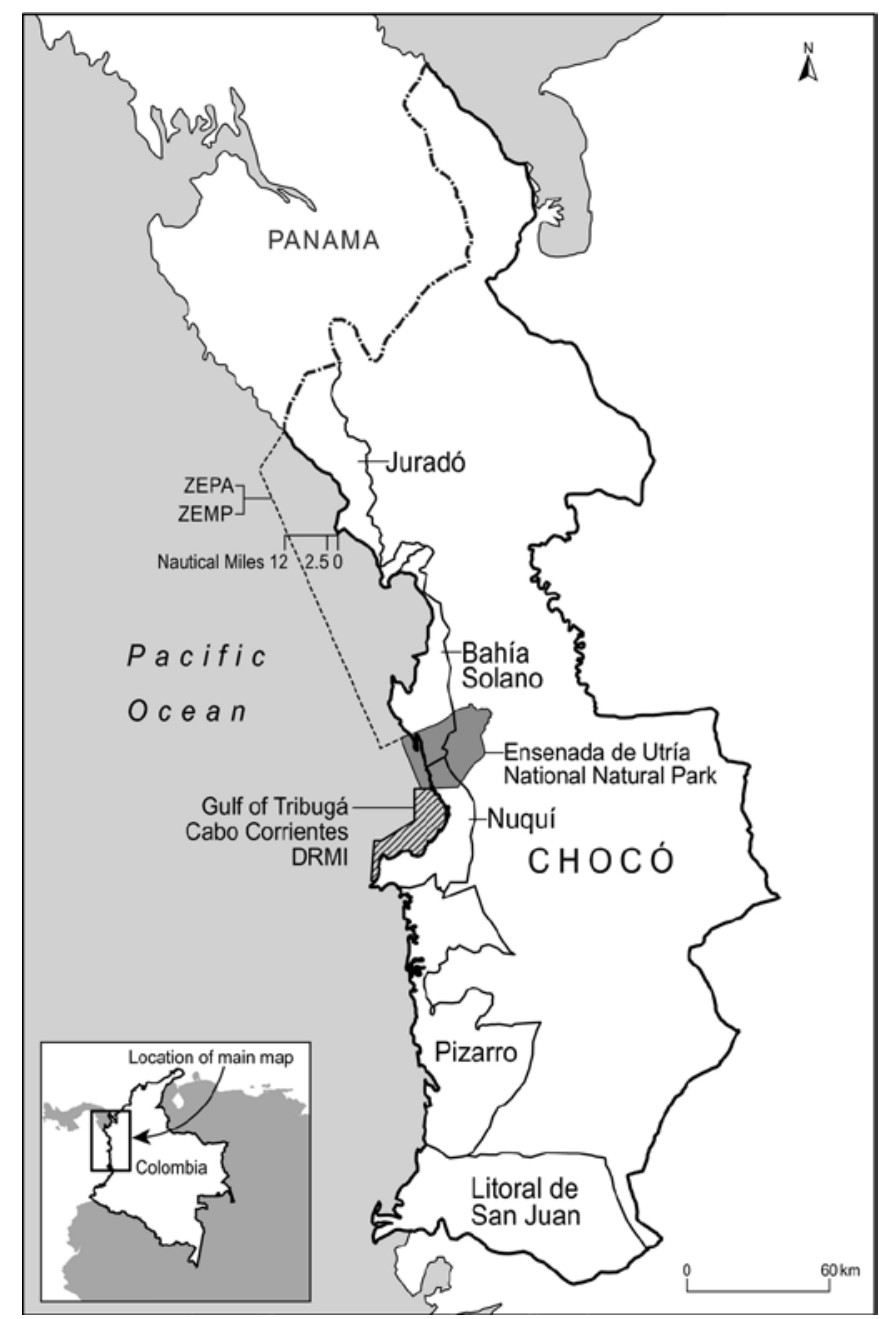

Figure 3. Map of the coastal municipalities and protected areas along the Pacific coast of the Chocó department (Copyright Chandra Jayasuriya).

MPAs in Colombia have limited interaction between state agencies at regional and national levels. The absence of municipal state agencies has restricted local level interactions, such that conservation NGOs have played a key role creating bridging mechanisms between state agencies and local people. But questions of quantity have predominated over quality, where poor fisheries governance and limited control has led to MPAs that exist on paper only (De Santo 2013). Importantly, tensions between exploitation and conservation agendas and their overlapping territorialities have made the production of MPAs a messy process. ${ }^{5}$ We now

\footnotetext{
${ }^{5}$ State maritime territorialisation processes along the Pacific and their jurisdictional authorities: 1) territorial waters, under national jurisdiction; 2) mangroves, rivers, coasts, and oceans are public goods, owned by the state; 3) national parks, jurisdiction of the National Natural Parks office; 4) exploitation zones, jurisdiction of the fisheries authority; 5) mangrove swamps, jurisdiction of the Ministry of Environment and Sustainable Development; 6) from the coastal baseline to $12 \mathrm{~nm}$, jurisdiction of Autonomous Regional Corporations; 7)
} 
show how this has opened some space for local communities to participate in the state production of territory at sea.

\section{Creating marine protected areas}

After many years of struggles between local communities and industrial fisheries in Juradó and Bahía Solano, small-scale fishers, fish traders, and the Interinstitutional and Community Group of Artisanal Fishing of the Chocó (GIC-PA) - which unites the efforts of private and public actors in support of small-scale fisheries in the northern Pacific - started pushing for the creation of a small-scale fishing zone. Finally, in 2008, the fisheries authority created a one-year provisional Exclusive Artisanal Fishing Zone (ZEPA) (Figure 3). This area goes from the coastal baseline out to $2.5 \mathrm{~nm}$, and it granted fishing rights to small-scale fishers, excluding industrial fishing. The Squalus Foundation, a national conservation NGO, signed a cooperation agreement with the fisheries authority and monitored the ZEPA for two years from 2008 and suggested an extension of the area to 5-7 nm from the shoreline, for the effective protection of local fish stocks. The fisheries authority ignored this and only extended the provisional status of ZEPA. A new cooperation agreement was signed with MarViva Foundation, an international conservation NGO, to undertake participatory monitoring of artisanal fish stocks from 2010 to 2012.

Tired of being ignored, small-scale fishers filed an Actio popularis in 2012, with the support of the national Social Justice Study Centre - Tierra Digna, arguing that the lack of control over industrial fisheries that continue to fish inside the ZEPA is a violation of their collective rights to a healthy environment and cultural heritage. A request to expand the area to $7 \mathrm{~nm}$ from the shoreline and more effective control over industrial vessels was filed at the Administrative Tribunal of Cundinamarca, whose decision is still pending. As mentioned by two academics involved in the process, local communities were defending the sea as part of their territories. After five years of provisional status, in 2013 the ZEPA became permanent. It was not enlarged, but the fisheries authority instead created a Special Fishing Management Zone adjacent to it (Figure 3). This area only bans the entry of tuna fisheries from 2.5 to 12 $\mathrm{nm}$ from the shoreline and still allows the entry of the deep-water shrimp vessels. However, neither of these MPAs are properly surveyed or enforced. Community members have reported illegal fishing several times, with no response from the fisheries authority. It appears that Colombia has rewarded quantity over quality in order to comply with the CBD marine conservation targets, in which MPAs like the Special Fishing Management Zone only exist on paper.

Despite these difficulties, and driven by the ZEPA experience, coastal communities in the Gulf of Tribugá engaged in the creation of a new MPA to legitimise local access and control over the sea, and to ban industrial fisheries. They have experienced conflicts with the deepwater shrimp boats that enters the Gulf to access El Filo, one of the most important pink shrimp fishing grounds. According to a community leader in Nuquí:

"Looking at ZEPA in Bahía Solano, where the industry was banned from trawling. We thought, why don't we organise and unite the communities to protect the resources,

marine traffic, jurisdiction of the Colombian Maritime Authority; 8) marine defence, jurisdiction of the Colombian National Navy. 
not for me, but for those that will come. That is the struggle for the MPA" (Supplementary Text S12).

These conflicts were first reported by the Natura Foundation (a conservation NGO) in the 1990s. Later in the Ethno-Development Plan, formulated by the Los Riscales community council in 2007, local fishers requested the creation of an artisanal fishing zone to protect small-scale fisheries from the impacts of the industry $(2007,266)$. As explained by a community leader in Jurubirá:

"The shrimp industry is not only catching shrimp, they catch everything [...] Our fishing grounds that we call riscales, those places are sacred for us, when industrial vessels come and drag they destroy these places. All this has prompted artisanal fishers to look for an instrument to protect these places at least from the industry" (Supplementary Text S13).

Similar allegations were made by respondents along the Gulf, who claimed industrial vessels were not only fishing in El Filo, but near their riscales, depleting fish stocks and destroying traditional fishing grounds. The idea of creating an MPA gained momentum when INVEMAR identified 12 national priority areas for marine conservation in the Pacific in 2008, from which two were located inside the Gulf of Tribugá (Alonso et al. 2008). With the support of MarViva Foundation, communities started monitoring fish catches to support local claims that fish stocks and fish size were declining, and designed the management plan for their mangroves in 2009. A year later, INVEMAR assessed the socio-economic viability of the MPA, determining the area would only be feasible if local autonomy were maintained, traditional knowledge is acknowledged, the management scheme involved local participation, and local living standards were improved (Maldonado et al. 2010). Based on these considerations, community workshops held in 2013 discussed different types of protected areas. As recalled by local leaders who attended the workshop, the possibility of creating a national park or ZEPA were dismissed. The conflictual relationship between fishers and park officials in the Ensenada de Utría, and the lack of funding for managing a ZEPA or Special Fishing Management Zone, prompted this decision. The Regional District of Integrated Management (DRMI), was chosen as the best option as it restricts fishing activities to sustainable practices, and receives funding from the Departmental System of Protected Areas. According to a community leader from Tribugá:

"We have studied the different protected areas that exist in the Colombian state, and started to think about which of these could be the best for this area. We decided to go with the DRMI, because it enables a sustainable use; we want it to be for the benefit of people, where decisions are taken with the communities" (Supplementary Text S14).

This model would enable the integration of marine and coastal areas, and support the implementation of a co-management scheme. As noted by a community leader in Nuquí:

"The ultimate goal of this area is the exercise of community political government. It is not just the environmental component that the state and NGOs are supporting, it is a sum of actions directed for the community to improve its living standard" (Supplementary Text S15). 
Community leaders were aware that MPA conservation objectives could potentially overpower local interests, but they lobbied for it as an opportunity to protect local communities from industrial fishing. The Gulf of Tribugá Environmental Ordinance Roundtable was formed to unify the MPA declaration efforts, involving the participation of the Los Riscales community council, the Autonomous Regional Corporation for Sustainable Development of Chocó - Codechocó, the fisheries authority, the Nuquí City Hall, and the National Army, with the support of the GIC-PA, tourism, fishing, and mangrove roundtables, National Natural Parks, NGOs, and INVEMAR. In 2014, communities from the nine coastal villages in the Gulf signed prior consultation agreements. Local respondents agreed to the creation of the DRMI to ban the industry from the Gulf. Respondents recalled attending community meetings and signing the previous consultation agreement although some were sceptical. The DRMI was declared by Codechocó the $18^{\text {th }}$ of December 2014 (Figure 3). This process emerged from the differential space produced by the state's terrestrial representations of Los Riscales collective territory, in which the sea is considered part of local peoples' territory. The difficulty has been that the industry, with the support from INVEMAR, claimed it fishes sustainably. According to a conservation NGO official:

"INVEMAR, who paradoxically promoted the creation of the protected area, in a study revealed that the deep-water shrimp is underexploited, and developed a management proposal for the industry that has been endorsed by the AUNAP [Fisheries authority] [...]. The DRMI formal agreement has a list of permitted practices that includes sustainable fishing, but there is no discrimination between trawling and artisanal fishing. The problem is that the agreement signed during the previous consultation, explicitly stated the area prohibits industrial fisheries" (Supplementary Text S16).

Consequently, the deep-water shrimp industry continues to fish inside the DRMI, threatening the local legitimacy of the MPA. Fishing agreements between the ordinance roundtable and the industry have been negotiated and are under construction (personal communication, April 2017). However, communities are not only dealing with power asymmetries within the ordinance roundtable, but are facing the challenges of assessing the sustainability of the deep-water shrimp industry and creating a comanagement scheme under limited and intermittent financial and technical support from Codechocó. Local efforts remain vulnerable and depend on individual actors and NGOs, who have played a major role lobbying for the development of cross-level and cross-scale linkages in a very unstable institutional context.

\section{Discussion and conclusion}

The land-sea divide enforced by the modern state gives a false impression of marine spaces as empty of people, and available for capital accumulation (Steinberg and Peters 2015). The empty-yet-full narratives of the Pacific coast of Colombia continue to reproduce colonial racial logics that neglect the existence of aquatic social processes and keep Afro-descendant marine territorial struggles invisible from the eyes of the state (Bridge 2001; Mollett 2015). On this basis, the state's production of territory has guaranteed external access and control over marine and terrestrial resource and wild frontiers, a process that has perpetuated social inequalities (Restrepo 2013; Serje 2013). These frontiers have also been tied to the 
production of places of violence, where local territorialities are constantly confronted by legal and illegal capital accumulation (Grajales 2011; Ojeda 2012; Vélez-Torres 2012). Afrodescendant territorial rights have been key for the recognition of local territorial struggles. However, collective territories inscribed in national legislation have also acted as a political technology to control rather than empower remote communities, creating land/water boundaries over fluid and dynamic geographies.

Coastal communities in the Gulf of Tribugá have not been passive observers in the state's production of territory. LAEs have informed and maintained a differential space, where territory is perceived as a place where culture and ancestral practices are created and transformed, entangled in complex fluid and volumetric spatio-temporal dynamics. These epistemologies are scaling up to shape state marine territorialisation, attempting to guarantee local access and control beyond the boundaries defined by their land-based collective territories. Drawing on Elden's definition of territory as a political technology, unlike land, the sea in the MPA is not a scarce resource distributed and owned, but is a 'central space of existence' for coastal fishing communities (Peters 2015, 271). Moreover, terrain has been constructed by the political knowledge-power relations at the confluence of LAEs and modern environmental conservation. This has enabled local differential space and territorial struggles to reach national political arenas, producing new fields of negotiation to transform relations of authority at sea. Epistemic plurality exists not only onshore (Escobar 2008) but also offshore within the state's complex territorialisation of the region.

As Corson (2011) argues, the neoliberal production of state territorialisation has been used by non-state actors to claim authority and control. We add to the understanding of these territorialisation processes by demonstrating that these negotiations at sea are limited by the framing of seascapes as public spaces that need to be enclosed to protect or regulate the use of resources. This framing has historically relegated the efforts of coastal dwellers in their defence of socio-cultural practices along the land-water interface.

The self-determination of Afro-descendant communities to assert territorial rights, using formal mechanisms of territorial control rather than dismissing them as impositions by the state, is an effort to redress their ongoing displacement from both land and sea. These communities are strategically navigating the logic of the state, taking advantage of the contradictions between resource and wild frontiers to participate in the process of state formation. Conservation NGOs have played a major role creating bridging mechanisms between local communities and environmental authorities, and supporting local processes linked to the creation of the MPA. The catch is that the MPA also subjects local communities to discourses and imaginaries of the sea as a space that needs to be regulated and protected, as well as introducing added value processes of commodification of nature. The latter link MPAs to the marketisation of sustainable fish products and ecotourism, through the brokering functions of NGOs and development aid agencies (Igoe and Brockington 2007). The extension of local politico-legal authority into the sea still involves power asymmetries between local communities and more powerful industrial fisheries. The political struggle for their territories continues. Moreover, local leaders from Pizarro and Litoral de San Juan, the two southern municipalities, have expressed their interest in developing similar participatory processes to the DRMI. Due to the pressure to meet MPAs targets, it is likely that other communities will develop analogous protection regimes, willing to go through cumbersome processes to ensure local access and control over the sea. Despite this, MPAs are not integrating land and marine territorial rights, but separating the socio-cultural dynamics from 
the water by focusing mainly on fisheries management. We call for the study and recognition of land/marine territorialisation alternatives through legal and political instruments to defend the right of amphibious peoples around the globe.

MPAs could be considered the lesser of evils, in comparison to previous rounds of territorialisation that saw the Pacific as a marine resource frontier ripe for exploitation. However, the state still governs industrial fisheries through market incentives in a neoliberal economy, making the sustainability of the region's operations questionable (Mansfield 2004a). The struggle over the control of resource frontiers in this unconventional conflict scenario is unique, placing communities and biodiversity conservation at the crossroads between legal and illegal territorialisation processes. Further research will be needed to move beyond MPAs as a solution for the lack of recognition of peoples’ coastal-marine territorial rights.

\section{Supporting Information}

\section{S1-S15: Original Spanish language interview data}

S1. "Aquí en el golfo esta la historia de lo que somos, nosotros somos todo lo que usted ve, somos mar, lluvia y selva."

S2. "Desde allí, desde mi niñez nace ese amor por la pesca. Porque pescar significa y simboliza para nosotros alegría, harmonía, la pesca es de suerte, de vivencia [...]. Cuando uno está mar abierto está conectado con la naturaleza, el pensamiento, el cuerpo y el alma esta sincronizado con el movimiento del mar.”

S3. "Parece que el gobierno es como si ellos estuvieran pensando esos negros no los vamos a dejar que se fortalezcan y nunca les vamos a dar autonomía.”

S4. "Lugar en donde se forja y fortalece la cultura, se preservan las practicas ancestrales, es mediado y construido por una cosmovisión para que dicho espacio tenga significados y sentidos.”

S5. "Muchos alegan que ellos tienen una incidencia sobre el territorio marino, y que la ley 70 que es la de las comunidades afrodescendientes dice que ellos ingieren sobre su territorio. Pero las otras leyes del país dicen que el territorio marino es del estado, punto."

S6. "La industria no nos respetan los sitios, nuestros caladeros. El año pasado había dos barcos metidos aquí arrastrando y se llevaron nuestros espineles. Nosotros pusimos queja, pero nos hemos dado cuenta de que muchos de esos dueños de barcos son gente que están bien cogidas con el gobierno, por eso no nos pararon muchas bolas.”

S7. “¡Ay eso es una pelea! le dicen a uno que el mar no tiene dueño, que el mar es de todo el mundo, el mar no es algo privado, así que los barcos le dicen a uno que ellos pagan un impuesto, que las grandes industrias ellas pagan un impuesto en Bogotá y que ellos tienen su licencia, que allá les dan el permiso. Pero ahora nosotros tenemos un reglamento que el estado le ha dado a uno para defender su territorio. Para que el blanco defienda el de él, el negro defienda el de él, y el indio defienda el de él, pero entonces ¿si eso nos lo dieron por qué tienen que venir de allá del Valle a destruir el Chocó?”

S8. “Acá no nos beneficiamos de nada de eso, ellos toda su producción es para sacarla, para llevarla a sus compañías y sí les afecta mucho a los pescadores acá."

S9. “Aquí para darle un espacio a los pescadores artesanales se les consulta a los industriales. Eso a mí, es una evidencia del desequilibrio y además de la alta influencia del sector industrial en el diseño de políticas. Aquí incluso podríamos 
cuestionar que lo que el gobierno llama 'participativo del sector industrial' como un obstáculo a la independencia de la toma de decisiones del gobierno."

S10. "En Enero, yo estaba en la playa Olímpica y un camaronero a menos de una milla, arrastrando. Llame al teniente de la armada y me dice 'yo estoy pendiente es del orden público con el tema del narcotráfico' [...]. La gente solo puede sentarse a llorar, de ver como esos barcos acaban con nuestro mar."

S11. "Viendo la ZEPA en Bahía Solano, en donde se les prohíbio a los industriales arrastrar, pensamos por qué no nos organizamos y nos unimos las comunidades para proteger el recurso, no para mí, sino para el que viene, esta es la lucha por el área marina protegida."

S12. "La industria camaronera, no solo capturan el camarón, va con todo [...] Nuestros sitios de pesca que nosotros les llamamos riscales, esos sitios para nosotros son sagrados y en el momento en que la flota industrial entra y arrastra nos desbaratan los sitios. Todo esto ha permitido que el pescador artesanal nos pellizquemos y digamos nosotros tenemos que buscar una figura donde nos proteja al menos lo sitios de la industria."

S13. "Nosotros hemos estudiado las diferentes clases de figuras que hay en el estado colombiano para poder pensar qué podría ser esta área. Nosotros decidimos que fuera el DRMI, porque permite una forma de uso sostenible, queremos que sea en beneficio para la gente, donde las decisiones se tomen con las comunidades."

S14. "El fin último del área es el desarrollo de la comunidad el ejercicio de la política del gobierno de la comunidad que se haga, no tanto el componente ambiental que le interesa al estado o las ONGs, es todo eso sumado a las acciones van es encaminadas a que la comunidad tenga una mejor calidad de vida."

S15. "INVEMAR que paradójicamente es también quien promovió la creación del área protegida, en una investigación arrojó que hay un recurso de camarón profundo que esta sub-explotado, y desarrolla una propuesta de manejo para la industría que está avalada por la AUNAP [...]. El acuerdo formal del DRMI tiene una lista de prácticas incluyendo pesca sostenible, en donde no está discriminando la pesca de arrastre de la pesca artesanal. El problema es que el acuerdo que se firmó cuando se hizo la consulta previa si tiene explicito que se prohíbe la pesca industrial."

\begin{tabular}{|c|c|c|}
\hline & & \\
\hline & Deep water shrimp & tuna \\
\hline Economic potential & $\begin{array}{l}\text { US\$ } 4.6 \text { million in } 2012 \\
\text { (Rodríguez et al. 2012) }\end{array}$ & Not available \\
\hline $\begin{array}{l}\text { Northern Pacific fishing } \\
\text { grounds }\end{array}$ & $\begin{array}{l}\text { Coliflor shrimp: Juradó and Bahía } \\
\text { Solano (September to December) } \\
\text { Pink shrimp: Gulf of Tribugá (El filo) } \\
\text { (May to June) } \\
\text { (Rodríguez et al. 2012) }\end{array}$ & Throughout the northern Pacific \\
\hline Fishing ban & $\begin{array}{l}\text { Spawning season, } \\
1^{\text {st }} \text { January to } 28^{\text {th }} \text { February (Resolution } \\
2311,2015 \text { ) }\end{array}$ & No ban \\
\hline Total fishing licenses & $\begin{array}{l}23 \text { National vessels (2016) (Resolution } \\
1964,2015)\end{array}$ & $\begin{array}{l}14 \text { National vessels, } 21 \text { foreign vessels (IATTC } \\
\text { Fishery Status Report No. 13, 2015) }\end{array}$ \\
\hline
\end{tabular}

Table S1. Deep-water shrimp and tuna industries economic potential, fishing ban periods and total fishing licenses in the Pacific coast of Colombia.

ABColombia 2015 Fuelling conflict in Colombia: the impacts of gold mining in Chocó ABColombia, London 17-31.

Rodríguez A, Rueda M, Viaña J, García C, Rico F, García L and Girón A 2012 Evaluación y manejo de la pesquería de camarón de aguas profundas en el Pacífico colombiano 2010-2012 INVEMAR, Santa Marta. 
Tierra Digna and Melo D 2015 La minería en Chocó, en clave de derechos. Investigación y propuestas para convertir la crisis socio-ambiental en paz y justicia territorial Centro de Estudios para la Justicia Social (CEJS) Tierra Digna, Bogotá 54-64.

Tubb D 2015 Muddy decisions: gold in the Chocó, Colombia The Extractive Industries and Society 2 (4) 722-733.

\section{References}

Agnew J 2011 Space and place in Agnew J and Livingstone D eds The SAGE handbook of geographical knowledge Sage, London 316-330.

Agnew J 1994 The territorial trap Review of International Political Economy 153-80.

Agnew J and Oslender U 2010 Overlapping territorialities, sovereignty in dispute Tabula Rasa 13 191-213.

Alonso D, Ramírez L F, Segura-Quintero C, Castillo-Torres P, Wals-chburger T and Arango N 2008 Hacia la construcción de un Subsistema Nacional de Áreas Marinas Protegidas en Colombia INVEMAR, Santa Marta.

Andrade G I 2009 ¿El fin de la frontera? reflexiones desde el caso colombiano para una nueva construcción social de la naturaleza protegida Revista de Estudios Sociales 32 48-59.

Asher K and Ojeda D 2009 Producing nature and making the state Geoforum 40 (3) 292-302.

Benjaminsen T A and Bryceson I 2012 Conservation, green/blue grabbing and accumulation by dispossession in Tanzania The Journal of Peasant Studies 39 (2) 335-355.

Bennett N J, Govan H, and Satterfield T 2015 Ocean grabbing Marine Policy 57 61-68.

Berlanga M and Faust 2007 We thought we wanted a reserve Conservation and Society 5 (4) 450-477.

Bocarejo D and Ojeda D 2016 Violence and conservation: beyond unintended consequences and unfortunate coincidences Geoforum 69 176-183.

Brad A, Schaffartzik A, Pichlera M and Planka C 2015 Contested territorialisation and biophysical expansion of oil palm plantations in Indonesia Geoforum 64 100-111.

Brenner N and Elden S 2009 Henri Lefebvre on state, space, territory International Political Sociology 3 353-377.

Bridge G 2001 Resource triumphalism Environment and Planning A 33 2149-2173.

Brondo K V and Bown N 2011 Neoliberal conservation, garifuna territorial rights and resource management in the cayos cochinos marine protected area Conservation and Society 9 91-105.

Brown J C and Purcell M 2005 There's nothing inherent about scale: political ecology, the local trap, and the politics of development in the Brazilian Amazon Geoforum 36 607-624.

Cardwell E and Thornton T F 2015 The fisherly imagination: the promise of geographical approaches to marine management Geoforum 64 157-167.

Chmara-Huff F 2014 Marine protected areas: territorializing objects and subjectivities EchoGéo 29 1-19.

Chuenpagdee R, Pascual-Fernández J J, Szeliánszky E, Alegret L J, Fraga J and Jentoft S 2013 Marine protected areas: rethinking their inception Marine Policy 39 234-240. 
Consejo Comunitario General Los Riscales 2007 Plan de Etnodesarrollo: Visión de vida de las comunidades negras del Golfo de Tribugá 2007-2020 Consejo Comunitario General Los Riscales, Chocó.

Corson C 2011 Territorialisation, enclosure and neoliberalism The Journal of Peasant Studies 38 (4) 703-726.

Cox K R 1991 Redefining ‘territory’ Political Geography Quarterly 10 5-7.

De Pourcq K, Thomas E, Arts B, Vranckx A, Léon-Sicard T and Van Damme P 2017 Understanding and resolving conflict between local communities and conservation authorities in Colombia World Development 93 125-135.

De Santo E M 2013 Missing marine protected area (MPA) targets Journal of Environmental Management 124 137-146.

Díaz-Ochoa J A and Quiñones R A 2008 Relationship of precipitation, freshwater input, and sea level height with the abundance of the white shrimp (Litopenaeus occidentalis; Street, 1871) off Buenaventura, Eastern Tropical Pacific Fisheries Research 92 (2) 148-161.

Foucault, M. 1995. Discipline and punish: the birth of the prison, 2nd ed. Vintage Books, New York.

Elden S 2013a The birth of territory University of Chicago Press, Chicago.

Elden S 2013b Secure the volume Political Geography 34 35-51.

Elden S 2010 Land, terrain, territory Process in Human Geography 34 (6) 799-817.

Escobar A 2015 Territorios de diferencia: la ontología política de los ‘derechos al territorio’ Cuadernos de Antropología Social $4125-38$.

Escobar A 2008 Territories of difference Duke University Press, Durham.

Escobar A 2003 Displacement, development, and modernity in the Colombian Pacific International Social Science Journal 55 (175) 157-167.

Escobar A 2001 Culture sits in places Political geography 20 (2) 139-174.

Fals Borda O 2002 Historia doble de la Costa. Resistencia en el San Jorge Universidad Nacional de Colombia, Banco de la República, El Áncora Editores, Bogotá.

Friedemann N S 1993 La saga del negro: presencia africana en Colombia Pontificia Universidad Javeriana, Bogotá.

García C, Tavera-Escobar H, Vieira C, Rincón C and Rentería E 2014 Fostering ethno-territorial autonomy Journal of Latin American Geography 13 (2) 117-152.

Grajales J 2011 The rifle and the title The Journal of Peasant Studies 38 (4) 771-792.

Grueso L, Rosero C and Escobar A 2003 The process of black community organizing in the southern Pacific coast of Colombia in Gutmann M C, Matos Rodríguez F V, Stephen L and Zavella P eds Perspectives on Las Américas Blackwell Publishers Ltd, Oxford 430-447.

Grundy-Warr C, Sithirinth M and Ming Li Y 2015 Volumes, fluidity and flows Political Geography 459395.

Helmreich S 2011 Nature/culture/seawater American Anthropologist 113 (1) 132e144.

Igoe J and Brockington D 2007 Neoliberal conservation: a brief introduction Conservation and Society 5 (4) 434-449.

Lefebvre H 1991 The production of space Wiley-Blackwell, Oxford. 
Maldonado J H, Moreno-Sánchez R, Mendoza S L, López Rodríguez A, Alonso D and Sierra-Correa P C 2010 Viabilidad socioeconómica del establecimiento de un AMP: la capacidad adaptativa de la comunidad de Nuquí (Chocó) INVEMAR, Santa Marta.

Mansfield B 2004a Neoliberalism and the oceans Geoforum 35 313-326.

Mansfield B 2004b Rules of privatization Annals of the Association of American Geographers 94 (3) 565-584.

Mansfield B 2001 Property regime or development policy? The Professional Geographer 53(3) 384-397.

Melo Saldarriaga G, Maldonado L F and Zapata Padilla L A 2011 Aspectos generales de la pesquería de atún en Colombia in Díaz J M, Vieira C and Melo G eds Diagnóstico de las principales pesquerías del Pacífico colombiano Fundación MarViva, Bogotá 217-242.

Mollett S 2015 The power to plunder Antipode 48 (2) 412-432.

Moore M 2015 A political theory of territory Oxford University Press, New York 15-33.

Moore M 2014 Which people and what land? Symposium 'Theories of territory beyond Westphalia' International Theory 6 (1) 121-40.

Mulrennan M E and Scott C H 2000 Mare Nullius: indigenous rights in saltwater environments Development and Change 31 681-708.

Nietschmann B 1995 Conservación, autodeterminación y el área protegida Costa Miskita, Nicaragua Mesoamérica 29 1-55.

Ng'weno B 2000 On titling collective property, participation, and natural resource management The World Bank, Washington D.C.

Offen K H 2003 The territorial turn Journal of Latin American Geography 2 (1) 43-73.

Ojeda D 2012 Green pretexts: ecotourism, neoliberal conservation and land grabbing in Tayrona National Natural Park, Colombia The Journal of Peasant Studies 39 (2) 357-375.

Oslender U 2016 The geographies of social movements Duke University, United States.

Oslender U 2012 The quest for counter-space in the Colombian Pacific coast region in Muteba Rahier J eds Black social movements in Latin America Palgrave Macmillan, New York 95-112.

Oslender U 2004 Fleshing out the geographies of social movements Political Gegraphy 23 957-985.

Oslender U 2002 ‘The logic of the river’ The Journal of Latin American Anthropology 7 (2) 86-1.

PCN 2008 Territorio y conflicto desde la perspectiva del Proceso de Comunidades Negras PCN Reporte Proyecto PCNLASA Otros saberes, Cali.

Peluso N L and Lund C 2011 New frontiers of land control Journal of Peasant Studies 38 (4) 667-81.

Peters K 2015 Drifting: towards mobilities at sea Transactions of the Institute of British Geographers 40 262-272.

Quijano A 2000 Coloniality of power, Eurocentrism and Latin America Nepantla 1 (3) 533-80.

Restrepo E 2013 El giro a la biodiversidad en la imaginación del Pacífico colombiano Revista Estudios del Pacífico Colombiano (1) 171-199.

Rodríguez A, Rueda M, Viaña J, García C, Rico F, García L and Girón A 2012 Evaluación y manejo de la pesquería de camarón de aguas profundas en el Pacífico colombiano 2010-2012 INVEMAR, Santa Marta. 
Rodríguez-Martínez R E 2008 Community involvement in marine protected areas Journal of Environmental Management 88 1151-1160.

Roth R J 2006 'Fixing’ the forest Annals of the Association of American Geographers 98 (2) 373-391.

Russ G R and Zeller D C 2003 From Mare Liberum to Mare Reservarum Marine Policy 27 75-78.

Saavedra-Díaz L M, Rosenberg A A and Martín-López B 2015. Social perceptions of Colombian small-scale marine fisheries conflicts Marine Policy 56 61-70.

Scannell L and Gifford R 2010 Defining place attachment Journal of Environmental Psychology 30 1-10.

Serje M 2013 El mito de la ausencia del estado Cahiers des Amériques Latines 71 95-117.

Serje M 2006 Geopolítica de la ocupación territorial de la nación en Colombia Gestión y Ambiente 9 (3) 21-28.

Sneddon C 2007 Nature's materiality and the circuitous paths of accumulation Antipode 39 (1) 167-93.

St. Martin K 2005 Disrupting enclosure in New England fisheries Capitalism Nature Socialism 16 (1) 63-80.

St. Martin K 2001 Making space for community resource management in fisheries Annals of the Association of American Geographers 91 (1) 122-142.

Steinberg P E 2013 Of other seas Atlantic Studies 10 (2) 156-169.

Steinberg P E 1999 Navigating to multiple horizons: towards a geography of ocean space Professional Geographer 51 366375.

Steinberg P E 2001 The social construction of the ocean Cambridge University Press, Cambridge.

Steinberg P and Peters K 2015 Wet ontologies, fluid spaces Environment and Planning D: Society and Space 33 247-264.

Tubb D 2015 Muddy decisions: gold in the Chocó, Colombia The Extractive Industries and Society 2 (4) 722-733.

UNODC and MINJUSTICIA 2016 Colombia explotación de oro de aluvión: evidencias a partir de percepción remota UNODC, Bogotá.

Vargas Sarmiento P and Ferro G 1999 Gente de mar y río de luna in Vargas Sarmiento P eds Construcción territorial en el Chocó. Vol. I: Historias regionales ICANH, Bogotá.

Vélez-Torres I 2012 Water grabbing in the Cauca basin Water Alternatives 5 (2) 431-449.

Wade P 1995 The cultural politics of blackness in Colombia American Ethologist 22 (2) 341-357.

West P, Igoe J and Brockington D 2006 Parks and peoples Annual Review of Anthropology 35 251-277.

Wielgus J, Zeller D, Caicedo-Herrera D and Sumaila R 2010 Estimation of fisheries removals and primary economic impact of the small-scale and industrial marine fisheries in Colombia Marine Policy 34 (3) 506-513.

Wood L J, Fish L, Laughren J and Pauly D 2008 Assessing progress towards global marine protection targets Oryx 42 (03) 340-351.

Zapata L A, Beltrán-León B S, Herrera J C, Jiménez-Tello P, Prieto L M, Baos R A, Guevara-Fletcher C et al. 2013 Evaluation of the current state of small pelagic fisheries in the Colombian Pacific Advances in Geosciences 33 (33) 63-68. 